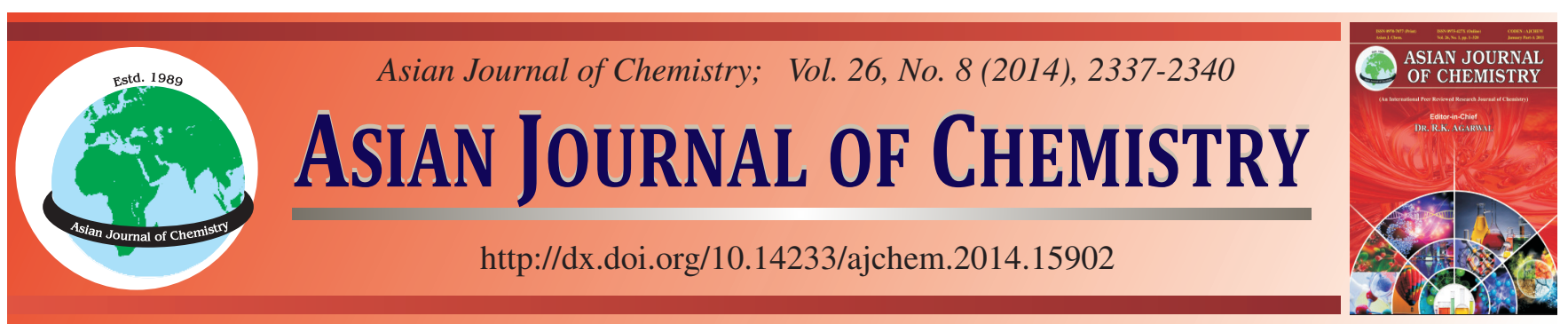

\title{
Synthesis, Characterization and Crystal Structure of 2D Copper(II) Complex with 6-Ethoxy-4',6'-dichloro-2,2'-[ethylenedioxybis(nitrilomethylidyne)]diphenol
}

\author{
W.-K. Dong ${ }^{*}$, W.-M. Zhou, X.-Y. Zhang, M.-M. Zhao, G. Li and X.-Y. Dong
}

School of Chemical and Biological Engineering, Lanzhou Jiaotong University, Lanzhou 730070, P. R. China

*Corresponding author: E-mail: dongwk@126.com

A new $\mathrm{Cu}(\mathrm{II})$ complex with asymmetric Salamo-type ligand, 6-ethoxy-4',6'-dichloro-2,2'-[ethylenedioxybis(nitrilomethylidyne)]diphenol $\left(\mathrm{H}_{2} \mathrm{~L}\right)$ has been synthesized and characterized by elemental analyses, FT-IR, UV-visible spectra and single crystal X-ray crystallography. The X-ray crystal structure of the $\mathrm{Cu}$ (II) complex reveals it to be a mononuclear structure, which contains one $\mathrm{Cu}$ (II) atom and one deprotonated $\mathrm{L}^{2-}$ unit. The center $\mathrm{Cu}$ (II) atom is tetra-coordinated, showing that the coordination sphere can be described as a square planar geometry distorted tetrahedrally by $33.07(4)^{\circ}$. In addition, the $\mathrm{Cu}(\mathrm{II})$ complex is linked to form an infinite $2 \mathrm{D}$ layer supramolecular structure through intermolecular $\mathrm{C}-\mathrm{H} \cdots \mathrm{O}$ and $\mathrm{C}-\mathrm{H} \cdots \mathrm{Cl}$ hydrogen bonds and $\pi \cdots \pi$ stacking interactions.

Keywords: Asymmetric Salamo-type ligand, $\mathrm{Cu}(\mathrm{II})$ complex, Synthesis, Crystal structure.

\section{INTRODUCTION}

Salen-type ligands and its derivatives are well-known chelating ligands in modern coordination chemistry ${ }^{1-3}$. During the past few decades, transition metal complexes of Salentype ligands, consisting of two oxygen and two nitrogen donors are of particular interest ${ }^{4,5}$. Factors that have contributed to the widespread and continued interest in Salen-type ligands are the initial recognition that metal complexes containing these types of ligands can reversibly bind oxygen ${ }^{6}$, the similarity between Salen-type ligands and heme, hence their use in model complexes $^{7}$ and finally, the more recent discovery of Salentype complexes as efficient chiral catalyst, a field which continues to be at the forefront of research efforts ${ }^{8,9}$. Furthermore, Salen-type $\mathrm{Cu}$ (II) complexes have been shown to their relevance as active site structures of metal-proteins and enzymes ${ }^{10}$ and partly because of attempts to understand the relationship between the structure and the spectroscopic properties ${ }^{11}$. Moreover, some Salen-type complexes have strong activity with $\mathrm{DNA}^{12}$ and can be used as elemental building blocks for construction of chain- or cyclic-like coordinated supramolecular structures ${ }^{13}$.

Herein, we report the synthesis, characterization and crystal structure of a $\mathrm{Cu}$ (II) complex with the new asymmetric Salamo-type ligand 6-ethoxy-4',6'-dichloro-2,2'-[ethylenedioxybis(nitrilomethylidyne)]diphenol $\left(\mathrm{H}_{2} \mathrm{~L}\right)$.

\section{EXPERIMENTAL}

2-Hydroxy-3-ethoxybenzaldehyde $(\geq 99 \%)$ and 2hydroxy-3,5-dichlorobenzaldehyde ( $\geq 99 \%)$ were purchased from Alfa Aesar and used without further purification. The others are the same as literature early ${ }^{14}$.

Synthesis of ligand $\mathrm{H}_{2} \mathrm{~L}$ : Synthetic route to the asymmetrical Salamo-type ligand $\mathrm{H}_{2} \mathrm{~L}$ is shown in Scheme-I. The ligand $\mathrm{H}_{2} \mathrm{~L}$ was synthesized with a slightly modified method reported literature $^{14 \mathrm{~g}}$. Yield $75.9 \%$. m.p. 379-381 K. Anal. Calcd. for $\mathrm{C}_{18} \mathrm{H}_{18} \mathrm{~N}_{2} \mathrm{O}_{5} \mathrm{Cl}_{2}$ (\%): C, 52.31; H, 4.39; N, 6.78. Found: C, 52.38; H, 4.47; N, 6.69.
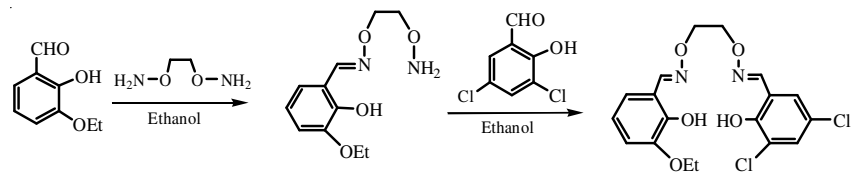

$\mathrm{H}_{2} \mathrm{~L}$

Scheme-I: Synthetic route to 6-ethoxy-4',6'-dichloro-2,2'- [ethylenedioxybis -(nitrilomethylidyne)]diphenol $\left(\mathrm{H}_{2} \mathrm{~L}\right)$

Synthesis of $\mathrm{Cu}(\mathrm{II})$ complex: A solution of $\mathrm{Cu}(\mathrm{OAc})_{2} \cdot \mathrm{H}_{2} \mathrm{O}$ (2 $\mathrm{mg}, 0.01 \mathrm{mmol})$ in methanol $(2 \mathrm{~mL})$ was added dropwise to a solution of $\mathrm{H}_{2} \mathrm{~L}(4.20 \mathrm{mg}, 0.01 \mathrm{mmol})$ in acetone $(4 \mathrm{~mL})$ at room temperature. The colour of the mixing solution turned to dark green immediately, then stirred for $45 \mathrm{~min}$ at room 
temperature. The mixture was filtered off and the filtrate was allowed to stand at room temperature for about six weeks, the solvent was partially evaporated and obtained brown rhombic single crystals suitable for $\mathrm{X}$-ray crystallographic analysis. Anal. Calcd. for $\mathrm{C}_{18} \mathrm{H}_{16} \mathrm{~N}_{2} \mathrm{O}_{5} \mathrm{Cl}_{2} \mathrm{Cu}(\%)$ : C, 45.54; H, 4.40; N, 5.90; Cu, 13.38. Found: C, 45.47; H, 4.49; N, 5.79; Cu, 13.42 .

X-Ray crystal structure determination: X-Ray structure determination is the same as literature early ${ }^{14 \mathrm{~h}}$. The crystal data and structure refinement for the $\mathrm{Cu}$ (II) complex are given in Table-1.

\begin{tabular}{|c|c|}
\hline \multicolumn{2}{|c|}{$\begin{array}{l}\text { CRYSTAL DATA AND STRUCTURE REFINEMENT } \\
\text { FOR Cu(II) COMPLEX }\end{array}$} \\
\hline Empirical formula & $\mathrm{C}_{18} \mathrm{H}_{16} \mathrm{~N}_{2} \mathrm{O}_{5} \mathrm{Cl}_{2} \mathrm{Cu}$ \\
\hline Formula weight & 474.77 \\
\hline Temperature (K) & $293(2)$ \\
\hline Wavelength $(\AA)$ & 0.71073 \\
\hline Crystal system & Monoclinic \\
\hline Space group & $\mathrm{P} 2(1) / \mathrm{c}$ \\
\hline Cell dimensions, $(\AA ̊$, deg) & $\begin{array}{l}a=11.3917(14), b= \\
10.7909(10) \\
c=15.331(2), \beta=94.962(2)\end{array}$ \\
\hline Volume $\left(\AA^{3}\right)$ & $1877.5(4)$ \\
\hline$Z$ & 4 \\
\hline Density (calculated) $\left(\mathrm{mg} / \mathrm{m}^{3}\right)$ & 1.680 \\
\hline Absorption coefficient $\left(\mathrm{mm}^{-1}\right)$ & 1.483 \\
\hline $\mathrm{F}_{(000)}$ & 964 \\
\hline Crystal size (mm) & $0.25 \times 0.24 \times 0.11$ \\
\hline Index ranges & $\begin{array}{l}-13 \leq \mathrm{h} \leq 8,-6 \leq \mathrm{k} \leq 12,-18 \leq 1 \\
\leq 16\end{array}$ \\
\hline Reflections collected & $6434 / 3310[\mathrm{R}(\mathrm{int})=0.0594]$ \\
\hline Independent reflections & 1290 \\
\hline Data/restraints/parameters & $3310 / 0 / 254$ \\
\hline Goodness of fit indicator & 1.029 \\
\hline $\mathrm{R}[\mathrm{I}>2 \sigma(\mathrm{I})]$ & $\mathrm{R}_{1}=0.0617, \mathrm{wR}_{2}=0.1461$ \\
\hline Largest diff. peak and hole $\left(\mathrm{e} \AA^{-3}\right)$ & 0.969 and -0.664 \\
\hline
\end{tabular}

\section{RESULTS AND DISCUSSION}

IR spectra of $\mathrm{H}_{2} \mathrm{~L}$ and its $\mathrm{Cu}(\mathrm{II})$ complex: The FT-IR spectra of $\mathrm{H}_{2} \mathrm{~L}$ and its corresponding $\mathrm{Cu}$ (II) complex exhibit various bands in the $4000-400 \mathrm{~cm}^{-1}$ region. The most important FT-IR bands for $\mathrm{H}_{2} \mathrm{~L}$ and its $\mathrm{Cu}$ (II) complex are given in Table-2.

\begin{tabular}{|c|c|c|c|c|}
\hline \multicolumn{5}{|c|}{$\begin{array}{c}\text { TABLE-2 } \\
\text { IR SPECTRAL DATA FOR H } \mathrm{H}_{2} \mathrm{~L} \text { AND } \\
\text { ITS Cu(II) COMPLEX }\left(\mathrm{cm}^{-1}\right)\end{array}$} \\
\hline Comp. & $v(\mathrm{C}=\mathrm{N})$ & $v(\mathrm{Ar}-\mathrm{O})$ & $v(\mathrm{O}-\mathrm{H})$ & $\begin{array}{l}v(\mathrm{C}=\mathrm{C}) \text { benzene } \\
\text { ring skeleton }\end{array}$ \\
\hline $\mathrm{H}_{2} \mathrm{~L}$ & 1611 & 1242 & 3395 & $1570,1495,1471$ \\
\hline $\begin{array}{c}\mathrm{Cu}(\mathrm{II}) \\
\text { complex }\end{array}$ & 1604 & 1211 & - & $1541,1475,1456$ \\
\hline
\end{tabular}

The characteristic $\mathrm{C}=\mathrm{N}$ stretching band of the free ligand $\mathrm{H}_{2} \mathrm{~L}$ appears at $1611 \mathrm{~cm}^{-1}$, while the $\mathrm{C}=\mathrm{N}$ band of the $\mathrm{Cu}$ (II) complex is observed at $1604 \mathrm{~cm}^{-1}$. The $\mathrm{C}=\mathrm{N}$ stretching frequency is shifted by about $7 \mathrm{~cm}^{-1}$ upon complexation, indicating a decrease in the $\mathrm{C}=\mathrm{N}$ bond order due to the coordination of the $\mathrm{Cu}(\mathrm{II})$ ion to the oxime nitrogen lone pair ${ }^{14-16}$. The Ar-O stretching band occurs at $1242 \mathrm{~cm}^{-1}$ for $\mathrm{H}_{2} \mathrm{~L}$, whereas that at $1211 \mathrm{~cm}^{-1}$ for the $\mathrm{Cu}$ (II) complex as reported for similar Salentype ligands ${ }^{17}$. This shift of Ar-O stretching frequency indicates that the $\mathrm{M}-\mathrm{O}$ bonds are formed between the $\mathrm{Cu}(\mathrm{II})$ ion and the phenolic $\mathrm{O}$ atoms of the deprotonated $\mathrm{L}^{2-}$ unit ${ }^{14}$. Meanwhile, a $\mathrm{O}-\mathrm{H}$ stretching band of the free ligand $\mathrm{H}_{2} \mathrm{~L}$ at $3395 \mathrm{~cm}^{-1}$ disappears in the $\mathrm{Cu}$ (II) complex, indicating the phenolic hydroxyl of the $\mathrm{Cu}$ (II) complex has been completely deprotonated and coordinated to the $\mathrm{Cu}$ (II) ion. In the $1570-1456 \mathrm{~cm}^{-1}$ region, the observed bands were attributed to aromatic $\mathrm{C}=\mathrm{C}$ vibrations.

UV-visible spectra of $\mathrm{H}_{2} \mathrm{~L}$ and its $\mathrm{Cu}$ (II) complex: The UV-visible spectra of $\mathrm{H}_{2} \mathrm{~L}$ and its corresponding $\mathrm{Cu}$ (II) complex in diluted DMF solution are presented in Table-3. The spectrum of the $\mathrm{Cu}$ (II) complex is different from the spectrum of the ligand $\mathrm{H}_{2} \mathrm{~L}$. The $\mathrm{UV}$-visible spectrum of the free ligand $\mathrm{H}_{2} \mathrm{~L}$ exhibits two intense absorption peaks at $282 \mathrm{~nm}$ and $321 \mathrm{~nm}$. The former absorption peak can be assigned to the $\pi-\pi^{*}$ transition of the benzene rings, while the latter one at $321 \mathrm{~nm}$ can be attributed to the intra-ligand $\pi-\pi^{*}$ transition of the $C=N$ bonds ${ }^{18}$.

For the $\mathrm{Cu}(\mathrm{II})$ complex, the $\pi-\pi^{*}$ transition of the benzene rings of benzaldehyde is slightly shifted in the $\mathrm{Cu}$ (II) complex and appears at $277 \mathrm{~nm}$. Meanwhile, the absorption peak disappears at $321 \mathrm{~nm}$ due to coordination of the $\mathrm{L}^{2-}$ unit in the $\mathrm{Cu}$ (II) complex, indicating that the oxime nitrogen atoms are involved in coordination to the $\mathrm{Cu}$ (II) atom ${ }^{19}$. In addition, a new moderate absorption peak appears at $376 \mathrm{~nm}$ in the $\mathrm{Cu}$ (II) complex, which is assigned to the $n-\pi *$ charge transfer transition from the filled $\mathrm{p}_{\pi}$ orbital of the bridging phenolic oxygen to the vacant $d$-orbital of the $\mathrm{Cu}(\mathrm{II})$ ion $^{20}$.

\begin{tabular}{cccc}
\multicolumn{4}{c}{ TABLE-3 } \\
& UV-VIS SPECTRA DATA OF H $\mathrm{H}_{2} \mathrm{~L}$ AND \\
\hline \multicolumn{4}{c}{ ITS Cu(II) COMPLEX } \\
\hline Comp. & $\mathrm{C}$ & First band & Second band \\
& $\left(\times 10^{-5} \mathrm{~mol} \mathrm{~L}^{-1}\right)$ & $\lambda_{\max }(\mathrm{nm})$ & $\lambda_{\max }(\mathrm{nm})$ \\
\hline $\mathrm{H}_{2} \mathrm{~L}$ & 5.00 & 282 & 321 \\
{$[\mathrm{Cu}(\mathrm{L})]$} & 5.00 & 277 & 376 \\
\hline
\end{tabular}

Crystal structure of $\mathbf{C u}(\mathrm{II})$ complex: The structure of the $\mathrm{Cu}(\mathrm{II})$ complex was determined by X-ray crystallography, revealing that the formation of a mononuclear structure (Fig. 1). Selected bond lengths and angles are listed in Table-4. $\mathrm{X}$-ray crystallographic analysis reveals that the $\mathrm{Cu}$ (II) atom lies in the $\mathrm{N}_{2} \mathrm{O}_{2}$ coordination sphere and crystallizes in the monoclinic system, space group P2(1)/c and the unit cell contains four $\mathrm{Cu}$ (II) complex molecules.

Each $\mathrm{Cu}(\mathrm{II})$ complex molecule contains one tetra-coordinated center $\mathrm{Cu}(\mathrm{II})$ atom and one deprotonated $\mathrm{L}^{2-}$ unit. The dihedral angle between the coordination plane of $\mathrm{O} 3-\mathrm{Cu}-\mathrm{N} 1$ and that of $\mathrm{O} 4-\mathrm{Cu}-\mathrm{N}_{2}$ is $33.07(4)^{\circ}$, indicating the coordination sphere can be described as a square planar geometry distorted tetrahedrally with $\mathrm{N} 2$ and $\mathrm{O} 3$ up average by $0.375(4)$ and $0.405(5) \AA$ and with N1 and O4 below average by $0.368(5)$ and 0.412 (3) $\AA$, respectively. Meanwhile, the $\mathrm{Cu}(\mathrm{II})$ atom is displaced by $0.030(3) \AA$ out of the basal plane of the donor (N1, N2, O4 and O3) atoms. The C1 and C2 atoms of the Oalkyl chain are also buckled asymmetrically from the $\mathrm{Cu}-\mathrm{N} 1-$ 


\begin{tabular}{cccccc}
\hline \multicolumn{7}{c}{ TABLE-4 } \\
& \multicolumn{5}{c}{ SELECTED BOND LENGTHS $(\AA)$ AND ANGLES $\left({ }^{\circ}\right)$ FOR THE Cu(II) COMPLEX } \\
\hline Bond & Lengths & Bond & Lengths & Bond & Lengths \\
\hline Cu1-O3 & $1.900(3)$ & Cu1-O4 & $1.912(4)$ & Cu1-N2 & $1.913(4)$ \\
Cu1-N1 & $2.016(4)$ & & & & Angles \\
\hline Bond & Angles & Bond & $155.0(2)$ & C10-N2-Cu1 & $129.1(4)$ \\
\hline O3-Cu1-O4 & $90.9(2)$ & O4-Cu1-N1 & $97.3(2)$ & O2-N2-Cu1 & $117.5(3)$ \\
O3-Cu1-N2 & $158.0(2)$ & N2-Cu1-N1 & $123.8(4)$ & C5-O3-Cu1 & $127.7(3)$ \\
O4-Cu1-N2 & $91.0(2)$ & C3-N1-Cu1 & C12-O4-Cu1 & $129.0(3)$ \\
O3-Cu1-N1 & $90.1(2)$ & O1-N1-Cu1 & $126.9(3)$ & &
\end{tabular}

$\mathrm{N} 2$ plane, with the displacement for $\mathrm{C} 1$ being $1.376(2) \AA$ toward the plane and for $\mathrm{C} 2$ being only 0.528(3) $\AA$ in the same direction. It is noteworthy that the $\mathrm{Cu}-\mathrm{N}$ bond lengths, 2.016(4) and $1.913(4) \AA$, are considerably longer than the $\mathrm{Cu}-\mathrm{O}$ bond lengths, 1.912(4) and 1.900(3) ̊., respectively.

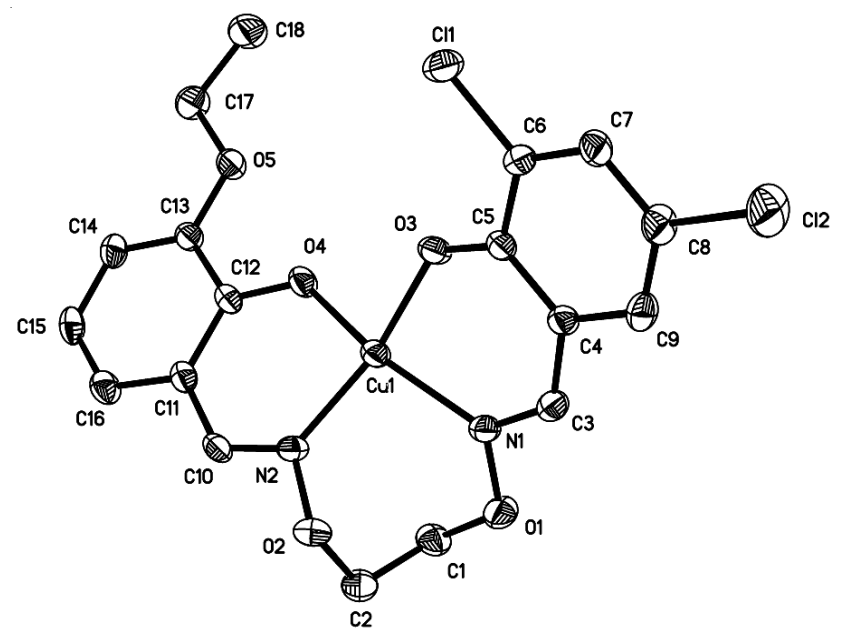

Fig. 1. Molecule structure of the $\mathrm{Cu}(\mathrm{II})$ complex with atom numbering scheme. Displacement ellipsoids for non-hydrogen atoms are drawn at the $30 \%$ probability level

Intermolecular interactions of $\mathbf{C u}$ (II) complex: The $\mathrm{Cu}$ (II) complex contains four intermolecular hydrogen bonds, $\pi \cdots \pi$ stacking interactions of neighboring six-membered rings. Hydrogen bond data are summarized in Table-5.

\begin{tabular}{|c|c|c|c|c|}
\hline \multicolumn{5}{|c|}{$\begin{array}{c}\text { TABLE-5 } \\
\text { DATA FOR INTERMOLECULAR } \\
\text { HYDROGEN-BONDING INTERACTIONS }\left(\AA{ }^{\circ}{ }^{\circ}\right)\end{array}$} \\
\hline D-H $\cdots A$ & $\mathrm{~d}(\mathrm{D}-\mathrm{H})$ & $\mathrm{d}(\mathrm{H} \cdots \mathrm{A})$ & $\mathrm{d}(\mathrm{D} \cdots \mathrm{A})$ & $\angle \mathrm{D}-\mathrm{H} \cdots \mathrm{A}$ \\
\hline $\mathrm{C} 1-\mathrm{H} 1 \mathrm{~B} \cdots \mathrm{O} 3$ & 0.97 & 2.54 & $3.110(7)$ & 118 \\
\hline $\mathrm{C} 2-\mathrm{H} 2 \mathrm{~A} \cdots \mathrm{O} 4$ & 0.97 & 2.53 & $3.210(7)$ & 127 \\
\hline $\mathrm{C} 1-\mathrm{H} 1 \mathrm{~A} \cdots \mathrm{O} 5$ & 0.97 & 2.70 & $3.388(6)$ & 129 \\
\hline C1-H1B $\cdots \mathrm{Cl} 1$ & 0.97 & 2.91 & $3.543(6)$ & 124 \\
\hline
\end{tabular}

Each $\mathrm{Cu}$ (II) complex links two other molecules in the same direction by four pairs of intermolecular $\mathrm{C} 1-\mathrm{H} 1 \mathrm{~B} \cdots \mathrm{O} 3$, $\mathrm{C} 2-\mathrm{H} 2 \mathrm{~A} \cdots \mathrm{O} 4, \mathrm{C} 1-\mathrm{H} 1 \mathrm{~A} \cdots \mathrm{O} 5$ and $\mathrm{C} 1-\mathrm{H} 1 \mathrm{~B} \cdots \mathrm{Cl1}$ hydrogenbonding interactions into an infinite $1 \mathrm{D}$ two-layer chain along the $\mathrm{b}$ axis (Fig. 2). The methylene $-\mathrm{C} 1 \mathrm{H} 1 \mathrm{~B}$ group of the $\mathrm{O}$-alkyl chain is respectively bound to the phenolic oxygen $\mathrm{O} 3$ atom and chloro $\mathrm{Cl} 1$ atom, as well as the methylene groups $(-\mathrm{C} 2 \mathrm{H} 2 \mathrm{~A}$ and $-\mathrm{C} 1 \mathrm{H} 1 \mathrm{~A})$ of the $\mathrm{O}$-alkyl chain are respectively bound to the phenolic oxygen $\mathrm{O} 4$ atom of the adjacent $\mathrm{Cu}$ (II) complex molecule and the ethoxy $\mathrm{O} 5$ atom.

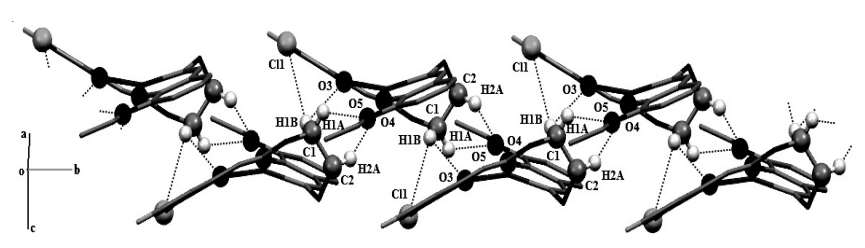

Fig. 2. View of 1D two-layer chain motif of the $\mathrm{Cu}(\mathrm{II})$ complex units along the $\mathrm{b}$ axis (hydrogen atoms, except those forming hydrogen bonds, are omitted for clarity)

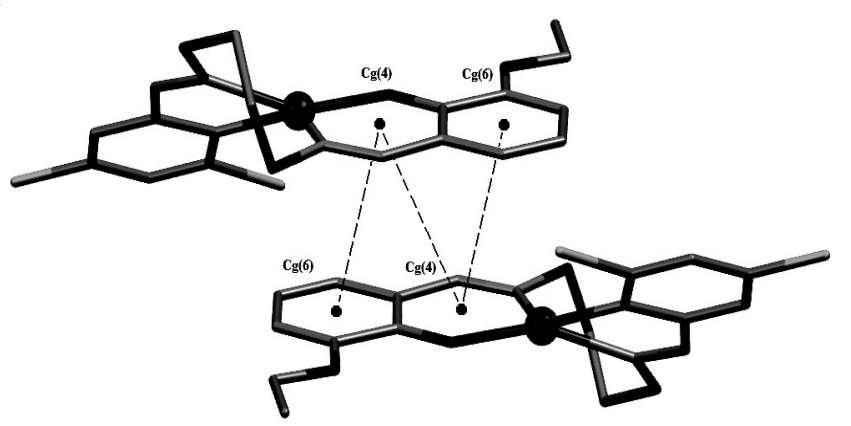

Fig. 3. View of the $\pi \cdots \pi$ stacking motif of neighboring six-membered rings of the $\mathrm{Cu}(\mathrm{II})$ complex

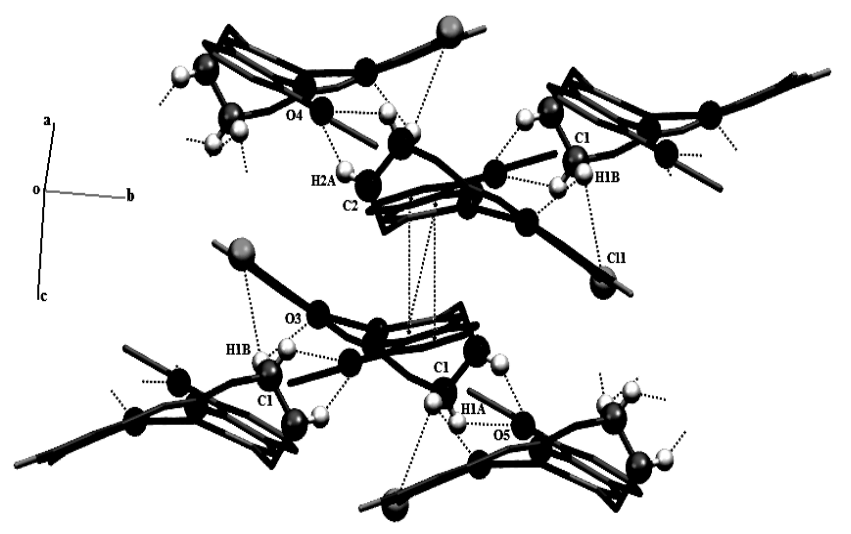

Fig. 4. View of the 2D layer supramolecular motif of the $\mathrm{Cu}(\mathrm{II})$ complex units on the bc crystallographic plane (hydrogen atoms, except those forming hydrogen bonds, are omitted for clarity)

Meanwhile, there exists three $\pi \cdots \pi$ stacking interactions between the six-membered rings ( $\mathrm{Cg} 4)$ containing $\mathrm{Cu}$ (II) atoms and the benzene ring $(\mathrm{Cg} 6)$ of the $\mathrm{L}^{2-}$ unit in the crystal structure, resulting in the $\mathrm{Cu}(\mathrm{II})$ complex comes in pairs, as shown in Fig. 3. Thus, every pair of the $\mathrm{Cu}$ (II) complexes link four other complex molecules to form an infinite 2D layer supramolecular structure (Fig. 4) through intermolecular $\mathrm{C}-\mathrm{H} \cdots \mathrm{O}, \mathrm{C}-\mathrm{H} \cdots \mathrm{Cl}$ hydrogen bonds and $\pi \cdots \pi$ stacking interactions. 


\section{ACKNOWLEDGEMENTS}

This work was supported by the Foundation of Gansu Province Traffic Transportation Dust Control Engineering Technology Research Center (513001-1), the Fundamental Research Funds for the Gansu Province Universities (212086) and the science and technology support funds of Lanzhou Jiaotong University (ZC2012003), which are gratefully acknowledged.

\section{REFERENCES}

1. D. Hall and T.N. Waters, J. Chem. Soc., 2644 (1960).

2. J. Reglinski, S. Morris and D.E. Stevenson, Polyhedron, 21, 2167 (2002).

3. A.D. Garnovskii, A.L. Nivorozhkin and V.I. Minkin, Coord. Chem. Rev., 126, 1 (1993).

4. Z.L. You, H.L. Zhu and W.S. Liu, Z. Anorg. Allg. Chem., 630, 1617 (2004).

5. Z.L. You and H.L. Zhu, Z. Anorg. Allg. Chem., 630, 2754 (2004).

6. D. Chen and A.E. Martell, Inorg. Chem., 26, 1026 (1987).

7. K. Oyaizu and E. Tsuchida, Inorg. Chim. Acta, 355, 414 (2003).

8. H.Q. Yang, L. Zhang, L. Zhong, Q. Yang and C. Li, Angew. Chem. Int. Ed., 46, 6861 (2007)

9. S. Jain, X. Zheng, C.W. Jones, M. Weck and R.J. Davis, Inorg. Chem., 46, 8887 (2007)

10. K.D. Karlin and Z. Tyeklar, Bioinorganic Chemistry of Copper, Chapman \& Hall, New York (1993).
11. A. Elmali, C.T. Zeyrek and Y. Elerman, J. Mol. Struct., 693, 225 (2004).

12. E.J. Gao, M.S. Chen, Y. Yu and Y.G. Sun, Chinese J. Struct. Chem., 26, 59 (2007).

13. S.S. Sun, C.L. Stern, S.T. Nguyen and J.T. Hupp, J. Am. Chem. Soc., 126, 6314 (2004).

14. (a) W.K. Dong, Y.X. Sun, C.Y. Zhao, X.Y. Dong and L. Xu, Polyhedron, 29, 2087 (2010); (b) W.K. Dong, Y.X. Sun, G.H. Liu, L. Li, X.Y. Dong and X.H. Gao, Z. Anorg. Allg. Chem., 638, 1370 (2012); (c) W.K. Dong, X.N. He, H.B. Yan, Z.W. Lv, X. Chen, C.Y. Zhao and X.L. Tang, Polyhedron, 28, 1419 (2009); (d) W.K. Dong, Y.X. Sun, Y.P. Zhang, L. Li, X.N. He and X.L. Tang, Inorg. Chim. Acta, 362, 117 (2009); (e) W.K. Dong, L. Li, C.F. Li, L. Xu and J.G. Duan, Spectrochim. Acta A, 71, 650 (2008); (f) W.K. Dong, J.Y. Shi, L. Xu, J.K. Zhong, J.G. Duan and Y.P. Zhang, Appl. Organometal. Chem., 22, 89 (2008); (g) W.K. Dong, S.J. Xing, Y.X. Sun, L. Zhao, L.Q. Chai and X.H. Gao, J. Coord. Chem., 65, 1212 (2012); (h) W.K. Dong, K.Q. Li, Y. Zhang, L. Xu, L. Wang and X.Y. Dong, Asian J. Chem., 25, 4398 (2013).

15. H.L. Wu, J.K. Yuan, Y. Bai, F. Jia, B. Liu, F. Kou and J. Kong, Transition Met. Chem., 36, 819 (2011).

16. H.L. Wu, K. Li, T. Sun, F. Kou, F. Jia, J.K. Yuan, B. Liu and B.L. Qi, Transition Met. Chem., 36, 21 (2011).

17. K. Ueno and A.E. Martell, J. Phys. Chem., 60, 1270 (1956).

18. T. Ghosh, B. Mondal, T. Ghosh, M. Sutradhar, G. Mukherjee and M.G.B. Drew, Inorg. Chim. Acta, 360, 1753 (2007).

19. H.E. Smith, Chem. Rev., 83, 359 (1983).

20. L. Gomes, E. Pereira and B. de Castro, J. Chem. Soc. Dalton Trans., 1373 (2000). 